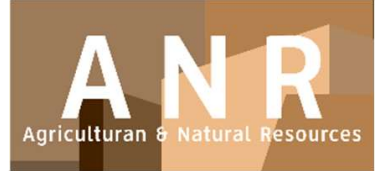

PAPER - OPEN ACCESS

Aplikasi Fungi Aspergillus niger, Aspergillus sp. 1, Aspergillus sp. 2 Untuk Meningkatkan Pertumbuhan Rhizophora apiculata Di Kecamatan Pangkalan Susukabupaten Langkat

$\begin{array}{ll}\text { Author } & : \text { Yunasfi dkk., } \\ \text { DOI } & : 10.32734 / \text { anr.v3i1.841 } \\ \text { Electronic ISSN } & : 2654-7023 \\ \text { Print ISSN } & : 2654-7015\end{array}$

Volume 3 Issue 1-2020 TALENTA Conference Series: Agriculturan \& Natural Resource (ANR)

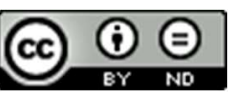

This work is licensed under a Creative Commons Attribution-NoDerivatives 4.0 International License.

Published under licence by TALENTA Publisher, Universitas Sumatera Utara

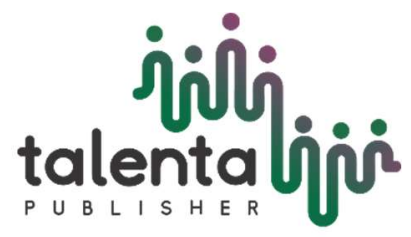


 \\ TALENTA Conference Series
}

Available online at https://talentaconfseries.usu.ac.id/anr

\section{Aplikasi Fungi Aspergillus niger, Aspergillus sp. 1, Aspergillus sp. 2 Untuk Meningkatkan Pertumbuhan Rhizophora apiculata Di Kecamatan Pangkalan Susukabupaten Langkat}

\author{
Yunasfi $^{a}$, Susi Soraya Silabana ${ }^{\text {a }}$, dan Budi Utomo ${ }^{\text {a }}$ \\ ${ }^{a}$ Fakultas Kehutanan,Universitas Sumatera Utara Jl. Tridarma Ujung No. 1 Kampus USU Medan 20155, Indonesia \\ yunasfijamhar@yahoo.co.id
}

\begin{abstract}
Abstrak
Hutan mangrove merupakan salah satu bentuk ekosistem hutan yang unik dan khas yang terdapat di daerah pasang surut di wilayah pesisir, pantai, dan pulau-pulau kecil. Alih fungsi lahan mangrove menjadi tambak, pemukiman, industri, dan kegiatan penebangan pohon-pohon mangrove akan berdampak pada rusaknya ekosistem ini. Dampak ekologis dari rusaknya ekosistem mangrove ini adalah terganggunya keseimbangan ekosistem mangrove. Alih fungsi hutan dapat diatasi dengan melakukan rehabilitasi ekosistem mangrove. Untuk mencapai tujuan tersebut dibutuhkan bibit yang sehat dan memiliki pertumbuhan yang cepat. Tujuan penelitian ini adalah untuk mengevaluasi jenis- jenis fungi yang diharapkan mampu meningkatkan pertumbuhan bibit mangrove $R$. apiculata . Penelitian ini menggunakan beberapa jenis fungi yaitu jenis fungi Aspergillus niger, Aspergillus sp. 1, Aspergillus sp. 2, dan kontrol. Sedangkan rancangan percobaan yang dilakukan dalam metode penelitian ini adalah Rancanan Acak Lengkap (RAL). Hasil penelitian ini menunjukkan fungi memiliki kemampuan yang berbeda-beda dalam meningkatkan laju pertumbuhan pada bibit $R$. apiculata yang berpengaruh nyata terhadap parameter diameter, tinggi, lebar daun. Dari hasil penelitian ini disimpulkan bahwa fungi Aspergillus niger memberikan manfaat yang baik bagi pertumbuhan mangrove.
\end{abstract}

Kata Kunci: Fungi; Mangrove; Pertumbuhan; Rhizhopora apiculata

\section{Pendahuluan}

Hutan mangrove merupakan salah satu bentuk ekosistem hutan yang unik dan khas yang terdapat di daerah pasang surut di wilayah pesisir, pantai, dan pulau - pulau kecil, baik sebagai tumbuhan yang terdapat di daerah pasang surut maupun sebagai komunitas. Mangrove juga didefinisikan sebagai formasi tumbuhan daerah litoral yang khas di pantai daerah tropis dan sub tropis yang terlindung. Kondisi hutan mangrove pada umumnya memiliki tekanan berat, sebagai akibat tekanan ekonomi yang berkepanjangan. Tekanan populasi, pengelolaan yang tidak memperhatikan aspek kelestarian, perkembangan industri dan perkotaan memberikan proporsi yang signifikan terhadap kerusakan hutan mangrove di negara yang sedang berkembang seperti Indonesia [1].

Masyarakat yang hidup di sekitar hutan mangrove sangat menggantungkan hidupnya pada kawasan mangrove karena melimpahnya sumber daya alam dan energi pada kawasan hutan mangrove tersebut. Seperti halnya dengan banyak dan luasnya hutan mangrove mampu meningkatkan populasi ikan yang hidup pada bagian akar tanaman bakau. Hutan mangrove juga berfungsi sebagai penyedia bahan makanan bagi kehidupan manusia terutama dalam kebutuhan ikan, udang, kerang-kerangan, kepiting, dan jenis organisme lainnya. Namun bila pemanfaatan hutan mangrove tidak dilakukan secara lestari akan menurunkan fungsi hutan mangrove tersebut [2]. 
Kerusakan tersebut antara lain disebabkan oleh konversi mangrove menjadi kawasan pertambakan, pemukiman, dan di bidang industri. Mangrove berfungsi sangat strategis dalam menciptakan ekositem pantai yang layak untuk kehidupan organisme akuatik. Keseimbangan ekologi lingkungan perairan pantai akan tetap terjaga apabila keberadaan mangrove dipertahankan karena mangrove dapat berfungsi sebagai biofilter, gen pengikat dan perangkap polusi serta mampu melindungi dari banjir dan erosi akibat naiknya air laut menuju ke daratan [3].

Indonesia memiliki tidak kurang dari 89 jenis pohon mangrove, atau paling tidak menurut FAO terdapat sebanyak 37 jenis. Dari berbagai jenis mangrove tersebut, yang hidup di daerah pasang surut, tahan air garam dan berbuah vivipar terdapat sekitar 12 famili. Dari sekian banyak jenis mangrove di Indonesia, jenis mangrove yang banyak ditemukan antara lain adalah jenis api-api (Avicennia sp.), bakau (Rhizophora sp.), tancang (Bruguiera sp.), dan bogem atau pedada (Sonneratia sp.) merupakan tumbuhan mangrove utama yang banyak dijumpai. Jenis-jenis mangrove tersebut adalah kelompok mangrove yang menangkap, menahan endapan dan menstabilkan tanah habitatnya. Mangrove besar, mangrove merah atau Red mangrove (Rhizophora sp.) merupakan jenis kedua terbaik. Jenis-jenis tersebut dapat mengurangi dampak kerusakan terhadap arus, gelombang besar dan angin [4].

Alih fungsi lahan mangrove menjadi tambak, pemukiman, industri, dan kegiatan penebangan pohon-pohon mangrove akan berdampak pada rusaknya ekosistem ini. Dampak ekologis dari rusaknya ekosistem mangrove ini adalah terganggunya keseimbangan ekosistem mangrove. Akibat dari terganggunya keseimbangan ekosistem mangrove salah satunya adalah hilangnya berbagai macam flora dan fauna yang berasosiasi dengan hutan mangrove [5].

Alih fungsi hutan dapat diatasi dengan melakukan rehabilitasi ekosistem mangrove. Untuk mencapai tujuan tersebut dibutuhkan bibit yang sehat yang memiliki pertumbuhan yang cepat. Dalam penelitian ini dimanfaatkan beberapa fungi yang mampu mempercepat proses dekomposisi bahan organik. Bahan organik yang telah terdekomposisi merupakan sumber hara bagi bibit $R$. apiculata. Sehingga cepatnya proses dekomposisi bahan organik diharapkan mampu mempercepat pertumbuhan bibit $R$. apiculata.

Beberapa jenis fungi memberikan pengaruh yang baik terhadap pertumbuhan $R$. apiculata seperti pada penelitian ini menggunakan fungi Aspergilusniger, Aspergilus sp. 1, Aspergillus sp. 2 dan pemberian fungi yang berbeda memberikan reaksi pertumbuhan yang berbeda juga. Berdasarkan hal inilah perlu dilakukan penelitian mengenai aplikasi beberapa jenis fungi untuk mengetahui kemampuan jenis fungi yang berpotensi meningkatkan pertumbuhan pohon pada ekosistem hutan mangrove dan dapat dimanfaatkan sebagai dekomposer alami.

Aspergillus niger merupakan salah satu spesies yang paling umum dan mudah diidentifikasi dari genus Aspergillus, famili Moniliaceae, ordo Monoliales dan kelas fungi imperfecti. A. niger dapat tumbuh dengan cepat, diantaranya digunakan secara komersial dalam produksi asam sitrat, asam glukonat dan pembuatan berapa enzim seperti amilase, pektinase, amiloglukosidase dan sellulase. A. niger dapat tumbuh pada suhu $35^{\circ} \mathrm{C}-37^{\circ} \mathrm{C}$ (optimum), $6^{\circ} \mathrm{C}-8^{\circ} \mathrm{C}$ (minimum), $45^{\circ} \mathrm{C}-47^{\circ} \mathrm{C}$ (maksimum) dan memerlukan oksigen yang cukup (aerobik). A. niger memiliki bulu dasar berwarna putih atau kuning dengan lapisan konidiospora tebal berwarna coklat gelap sampai hitam. Kepala konidia berwarna hitam, bulat, cenderung memisah menjadi bagian-bagian yang lebih longgar dengan bertambahnya umur. Konidiospora memiliki dinding yang halus, hialin tetapi juga berwarna coklat. A.niger dalam pertumbuhannya berhubungan langsung dengan zat makanan yang terdapat dalam substrat, molekul sederhana yang terdapat di sekeliling hifa dapat langsung diserap sedangkan molekul yang lebih kompleks harus dipecah dahulu sebelum diserap ke dalam sel, dengan menghasilkan beberapa enzim ekstra seluler. Bahan organik dari substrat digunakan oleh $A$. niger untuk aktivitas transport molekul, pemeliharaan struktur sel dan mobilitas sel [6].

\subsection{Tujuan Penelitian}

Tujuan penelitian ini adalah untuk mengevaluasi aplikasi fungi A.niger,Aspergillus sp. 1, Aspergillus sp. 2, dalam meningkatkan pertumbuhan R.apiculata di Kecamatan Pangkalan Susu Kabupaten Langkat.

\subsection{Manfaat Penelitian}

Penelitian ini diharapkan dapat menambah pengetahuan terkait manfaat pemberian fungi A. niger, Aspergillus sp. 1, Aspergillus sp. 2, dalam meningkatkan pertumbuhan $R$. apiculata. 


\section{Metode Penelitian}

\subsection{Lokasi dan Waktu Penelitian}

Pemanfaatan berbagai jenis fungi yang terdapat pada tanah dan air dari tempat tumbuh $R$. apiculata. Penelitian ini dilakukan pada bulan Agustus sampai November 2018 di Hutan Mangrove Kecamatan Pangkalan Susu Kabupaten Langkat. Pembiakan dan Identifikasi fungi dilakukan di Laboratorium Hama dan Penyakit Tumbuhan Fakultas Pertanian Universitas Sumatera Utara.

\subsection{Alat dan Bahan}

Alat yang digunakan dalam penelitian ini adalah labu Erlenmeyer, Gelas Beker, kompor, Tabung Reaksi, cawan Petri, Jarum Ose, Gelas Objek, Gelas Penutup, oven, Mikroskop Cahaya,Timbangan Analitik, Kalifer, Lampu Bunsen, Kamera, gunting, penggaris.

Bahan yang digunakan pada penelitian ini adalah bibit mangrove $R$. apiculata berumur 3 bulan untuk di tanam di lapangan, kayu pancang, spidol (alat tulis), tali rafia, alkohol, akuades, kertas tissue, kapas, kentang, dextrose, agar, masker, kertas stensil, aluminium foil, kertas label.

\subsection{Prosedur Kerja}

\subsubsection{Pembuatan PDA}

Pembuatan Media Potato Dextrose Agar (PDA) dengan menggunakan bahan kentang 200 gram yang diiris tipis. Kentang direbus dengan $1000 \mathrm{ml}$ aquades, selama 15-20 menit, kemudian disaring untuk mendapatkan filtrat kentang. Agar-agar 20 gram dimasukkan ke dalam filtrat hasil rebusan kentang, selanjutnya dimasak sampai mendidih dan diaduk sampai tidak terdapat endapan. Setelah suhunya normal dimasukkan antibiotik. Media PDA dimasukkan ke dalam Labu Erlenmeyer, kemudian disterilkan menggunakan autoclave dengan suhu $121^{\circ} \mathrm{C}$ dan tekanan $1,5 \mathrm{~atm}$ selama 15 menit dan disimpan dirak kultur untuk menghindari pertumbuhan mikroorganisme lain. Sebelum melakukan penuangan media, ditambahkan 0,1 gram Chlorompenicol.

\subsubsection{Peremajaan Fungi}

Media PDA dipanaskan hingga mencair, cawan Petri yang telah steril disiapkan. Media PDA dimasukkan ke dalam cawan Petri sampai seluruh cawan terisi. Fungi yang telah diisolasi sebelumnya diambil sedikit yaitu $1 \mathrm{~cm} \times 1 \mathrm{~cm}$ sebagai inang dan dimasukkan kedalam cawan Petri. Cawan Petri yang berisi fungi kemudian disimpan dan ditunggu sampai fungi tersebut tumbuh dan berkembang.

\subsubsection{Aplikasi Fungi}

Setelah 2 minggu penanaman. Proses pembuatan suspensi fungi yang akan diaplikasikan Setelah dilakukan penanaman R.apiculata, diaplikasikan fungi yang didapat dari hasil peremajaan fungi kebibit tanaman R. apiculata. Tiap jenis fungi dibuat 5 kali ulangan sesuai dengan perlakuan. Jenis-jenis fungi yang telah disiapkan untuk penelitian diaplikasikan dengan cara membuat suspensi fungi. Fungi yang tumbuh di media PDA diambil $1 \mathrm{~cm} \times 1 \mathrm{~cm}$, selanjutnya fungi ini dimasukkan ke dalam air steril $10 \mathrm{ml}$ pada tabung reaksi. Fungi yang ada dalam tabung reaksi ini selanjutnya dikocok, sampai fungi terlepas dari agar.

\subsubsection{Rancangan Percobaan}

Penelitian ini menggunakan Rancangan Acak Lengkap (RAL) Non Faktorial yaitu 4 perlakuan dengan10 ulangan. Pengumpulan data dilakukan setelah penanaman bibit dan pemberian fungi di lapangan, selama waktu sebagai berikut :
a. Hari ke-15 d.Harike-60
b. Hari ke-30 e. Hari ke-75
c. Hari ke-45 f. Hari ke-90 
Adapun jenis fungi yang dapat digunakan untuk meningkatan pertumbuhan $R$. apiculata berasal dari percoban sebelumnya, yaitu:
A. Kontrol
B. Aspergillus niger
C. Aspergillus sp. 1
D. Aspergillus sp. 2

Penetapan jenis-jenis fungi ini untuk membantu meningkatkan pertumbuhan $R$. apiculata didasarkan pada jumlah populasi fungi terbanyak diantara jenis- jenis fungi yang telah berhasil di isolasi dari tanah dan air tempat tumbuh $R$. apiculata, untuk setiap plot terdapat 40 bibit dengan 4 perlakuan dan 10 ulangan dengan jumlah 160 bibit. Penelitian yang dilakukan bersifat ekperimental dengan menggunakan Rancangan Acak Lengkap (RAL) Non Faktorial.

Model linier pada rancangan acak lengkap adalah seperti :

$$
Y_{i j}=\mu+\alpha_{i}+\sum_{i j}
$$

$\mathrm{Y}_{\mathrm{ij}} \quad=$ Pengamatan pada perlakuan fungi ke-i dan ulangan ke-j

$\mu \quad=$ Nilai rataan umum pengamatan

$\alpha_{i} \quad=$ Faktor pemberian fungi ke-i; $i=1,2, \ldots \ldots . t$ dan ulangan ke- $j=1,2, \ldots \ldots r$

$\sum_{\mathrm{ij}} \quad=$ Pengaruh galat pemberian fungi ke-i dan ulangan ke-j

\subsubsection{Parameter yang Diamati}

Pengukuran tinggi semai dilakukan sekali dua minggu selama tiga bulan. Alat ukur yang digunakan adalah penggaris dengan ketelitian $1 \mathrm{~cm}$. Pengukuran tinggi dimulai dari batang dimana daun pertama muncul, demikian dengan pengukuran selanjutnya sehingga data yang diperoleh lebih akurat. Diameter batang diukur dengan menggunakan kalifer. Untuk mendapatkan pengukuran yang lebih akurat diameter batang diukur dari batang dimana daun pertama muncul. Pada saat pengamatan dihitung semua jumlah daun dari bibit dan mengukur lebar daun terlebar.

\section{Hasil dan Pembahasan}

Pengamatanan pengukuran yang dilakukan terhadap bibit $R$. apiculata selama 12 minggu menunjukkan perbedaan terhadap pertambahan tinggi, diameter, luas daun terlebar, jumlah daun. Data pengamatan bibit $R$. apiculata tersaji pada Tabel 1 .

Tabel 1. Hasil Pengamatan Bibit R.apiculata 12 Minggu Setelah Tanam

\begin{tabular}{|l|l|l|l|l|l|}
\hline Parameter Pengamatan & Perlakuan & \multicolumn{5}{l|}{ Satuan } \\
\hline & Kontrol & A.niger & A. sp.1 & A.sp. 2 & 30.72 \\
\hline Tinggi rata- rata* & 25.90 & 36.48 & 28.28 & Cm \\
\hline Diameter rata-rata* & 0.66 & 0.96 & 0.71 & 0.76 & Cm \\
\hline Lebar daun terlebar* & 2.35 & 4.05 & 3.02 & 3.33 & Cm \\
\hline Jumlah daun & 9 & 10 & 9 & 9 & Helai \\
\hline
\end{tabular}

*Berpengaruh nyata berdasarkananalisis sidik ragam pada taraf $5 \%$

Hasil pengamatan yang dilakukan terhadap bibit $R$. apiculata untuk semua parameter menunjukkan bahwa adanya peningkatan pertumbuhan bibit, baik dalam penambahan tinggi bibit, pertambahan diameter batang, lebar daun terlebar dan jumlah daun. Nilai laju pertumbuhan hanya dihitung pada bentuk pertumbuhan vegetatif tanaman yang bersifat irreversible atau tidak dapat kembali seperti semula, yaitu tinggi diameter, lebar daun, dan jumlah daun. Data mengenai laju pertumbuhan tersaji pada Tabel 2 . 


\begin{tabular}{|l|l|l|l|l|l|}
\hline Parameter Pengamatan & Perlakuan & \multicolumn{4}{|l|}{ Satuan } \\
\hline & Kontrol & A.niger & A. sp.1 & A.sp. 2 & Cm/12 minggu \\
\hline Tinggi rata- rata & 6.49 & 16.45 & 8.15 & 9.49 & Cm/12 minggu \\
\hline Diameter rata-rata & 0.09 & 0.15 & 0.1 & 0.1 & 0.99 \\
\hline Lebar daun terlebar & 1.07 & 1.45 & 1.0 & 3 & Cm/12 minggu \\
\hline Jumlah daun & 3 & 4 & 3 & Helai/12 minggu \\
\hline
\end{tabular}

Perhitungan nilai laju pertumbuhan dilakukan dengan mengurangkan nilai pada data pengamatan terakhir dengan nilai pada pengamatan pertama, sehingga nilai pada hasil pengurangan tersebut yang akan menjadi nilai laju pertumbuhan pada bibit $R$. apiculata.

\subsection{Tinggi Bibit}

Berdasarkan hasil pengukuran yang dilakukan selama 12 minggu, diketahui bahwa semua bibit $R$. apiculata yang diberikan perlakuan aplikasi berbagai jenis fungi menunjukkan pertumbuhan yang lebih baik dibandingkan dengan kontrol. Pertambahan tinggi terbesar terdapat pada bibit $R$. apiculata di lokasi pulau sembilan dengan perlakuan $A$. niger dengan tinggi rata-rata $36,40 \mathrm{~cm}$ sedangkan yang terendah terdapat pada kontrol dengan tinggi $25,90 \mathrm{~cm}$. Pertambahan tinggi setiap minggu tersaji pada Gambar 3.

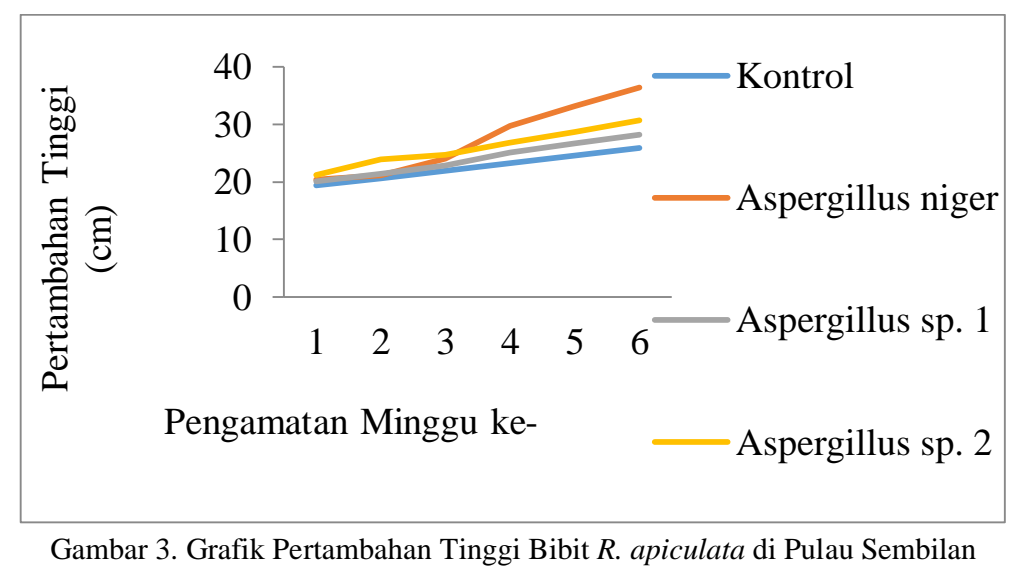

Hasil pengamatan juga menunjukkan bahwa pertambahan tinggi bibit $R$. apiculata lebih besar terdapat pada perlakuan fungi $A$. niger dengan tinggi rata-rata $36,48 \mathrm{~cm}$ sedangkan yang terendah terdapat pada bibit pada yang tidak diberikan perlakuan yaitu hanya $25,90 \mathrm{~cm}$. Pertambahan tinggi setiap minggu di daerah Pulau Sembilan memberikan gambaran bahwa setiap fungi yang diberikan berpengaruh terhadap pertumbuhan tinggi bibit $R$. apiculata walaupun dengan tingkat laju pertumbuhan yang berbeda-beda.

Berdasarkan hasil pengamatan tinggi tanaman yang diuji dengan analisis sidik ragam, dapat diketahui bahwa aplikasi pemberian fungi berpengaruh nyata terhadap pertambahan tinggi tanaman. Tinggi bibit $R$. apiculata adalah yang paling baik pertumbuhannya diantara bibit $R$. apiculata lainnya yang diberikan perlakuan fungi adalah tanaman dengan perlakuan fungi $A$. niger dengan tinggi tanaman $36,48 \mathrm{~cm}$. Hal ini disebabkan karena tingkat nutrisi yang dibutuhkan tanaman bertambah dengan adanya peran dekomposisi bahan organik yang dilakukan oleh fungi-fungi tersebut.

Dekomposisi bahan organik yang dilakukan oleh fungi tersebut berasal dari hasil proses perombakan bahan organik yang dilakukan oleh fungi $A$. niger. A. niger merupakan salah satu fungi yang tergolong kedalam jenis fungi yang berperan sebagai perombak bahan organik dalam bentuk unsur hara $\mathrm{N}$ yang diuraikan kedalam tanah.Fungsi unsur hara $\mathrm{N}$ sendiri dimanfaatkan oleh tumbuhan untuk merangsang pertumbuhan vegetatif yaitu penambahan tingginya tanaman. Untuk nilai laju pertumbuhan tertinggi, terdapat pada bibit $R$. apiculata yang diberikan perlakuan fungi $A$. 
niger dengan 16,45 cm/12 minggu. Sehingga dapat diartikan bahwa pertambahan tinggi bibit $R$. apiculata yang diberikan fungi jenis $A$. niger meningkatkan pertumbuhan tinggi bibit sebesar 16,45 cm selama 12 minggu pada lokasi pulau sembilan yang dianggap sebagai kawasan yang terbebas dari logam berat hasil limbah industri ataupun yang berasal dari aktivitas masyarakat. Berdasarkan nilai tersebut dapat diketahui bahwa fungi mampu menigkatkan kemampuan fungi dalam meningkatkan pertumbuhan bibit pada daerah yang kandungan logam beratnya rendah.

Hal ini disebabkan oleh kemampuan fungi jenis A. niger yang merupakan jenis pelarut unsur hara bentuk fosfat (P) yang berada didalam tanah. Unsur hara ini merupakan unsur hara yang dibutuhkan oleh tanaman untuk kemampuan pembelahan sel yang terjadi pada pertumbuhan bibit. Aspergillus merupakan mikroorganisme eukariot, saat ini diakui sebagai salah satu diantara beberapa makhluk hidup yang memiliki daerah penyebaran paling luas serta berlimpah di alam, selain itu jenis kapang ini juga me rupakan kontaminan umum pada berbagai substrat di daerah tropis maupun subtropis.

\subsection{Diameter Bibit}

Pemberian fungi pada lokasi Pulau Sembilan memberikan pengaruh nyata terhadap diameter bibit $R$. apiculata. Hasil pengukuran diameter tertinggi terdapat pada bibit $R$. apiculata yang tidak diberikan perlakuan yaitu sebesar 0,96 $\mathrm{cm}$. Sedangkan diameter terkecil terdapat pada bibit yang tidak diberi perlakuan (kontrol) dengan diameter 0,66 $\mathrm{cm}$. Pada setiap bibit dapat dilihat adanya perubahan dan pertambahan diameter yang dilakukan pengamatan sebanyak 6 kali yang terlampir pada Lampiran 2. Adapun grafik yang diperoleh dari hasil pengamatan pada pertambahan diameter bibit $R$. apiculata yang dilakukan pengamatan setiap 2 minggu sekali tersaji pada Gambar 4.

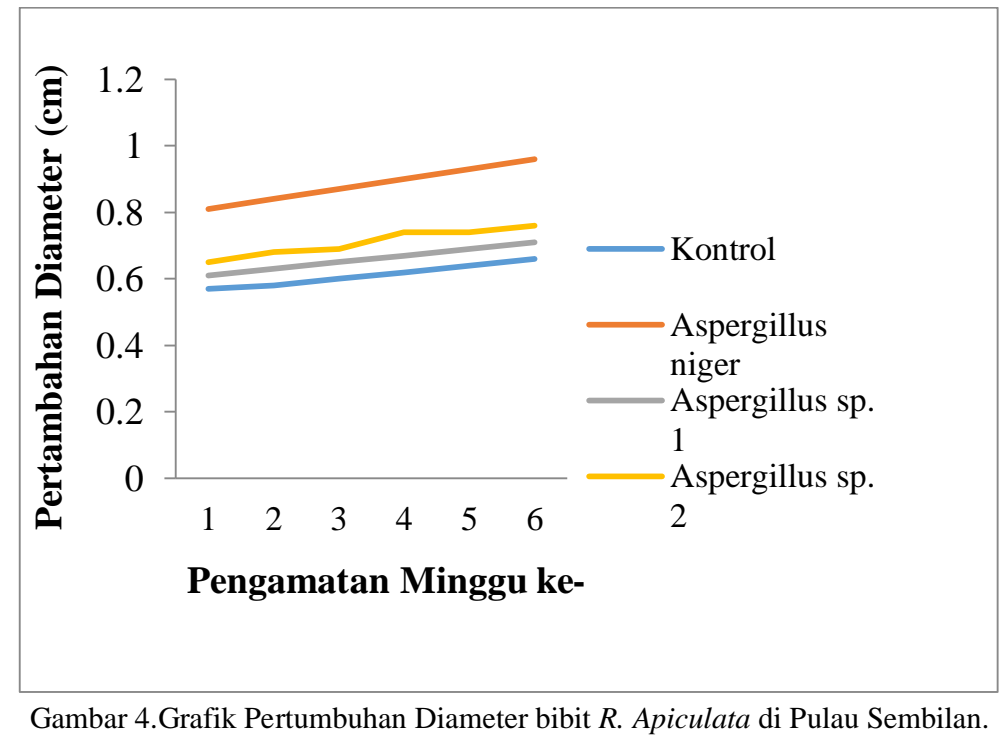

Berdasarkan hasil pengamatan yang dilakukan di lapangan selama 12 minggu, rata-rata pertumbuhan diameter tertinggi terjadi pada bibit tanpa adanya perlakuan pemberian fungi dengan diameter rata-rata $0,96 \mathrm{~cm}$, sedangkan bibit $R$. apiculata yang memiliki diameter terendah terdapat pada bibit $R$. apiculatan yang tidak diberikan perlakuan (kontrol) dengan diameter rata-rata $0,66 \mathrm{~cm}$. Namun dengan melakukan uji analisis sidik ragam $5 \%$ membuktikan adanya pengaruh nyata pemberian fungi terhadap pertumbuhan diameter bibit $R$. apiculata

Aplikasi fungi memberikan pengaruh terhadap pertumbuhan $R$. apiculata. Fungi Aspergillus sp. mampu melarutkan alumunium fosfor dan ferum fosfor [7]. Fosfor relatif tidak mudah tercuci, tetapi karena pengaruh lingkungan $\mathrm{P}$ tersedia berubah menjadi tidak tersedia [8], sehingga dengan adanya aktivitas Aspergillus sp. mampu mengubah $\mathrm{P}$ tidak tersedia menjadi tersedia. Aspergillus sp. juga memiliki kemampuan menghasilkan enzim urea reduktase dan fosfatase yang berperan dalam penambatan $\mathrm{N}$ bebas dari udara dan pelarut $\mathrm{P}$ dari senyawa yang sukar larut. Selain itu fungi tersebut mampu menghasilkan asam-asam organik pelarut $\mathrm{P}$ dan/atau polisakarida yang berfungsi sebagai perekat dalam pembentukan agregat mikro [9]. Peran mikroba tanah dalam siklus berbagai unsur 
hara di dalam tanah sangat penting, sehingga bila salah satu jenis mikroba tersebut tidak berfungsi maka akan terjadi ketimpangan dalam daur unsur hara di dalam tanah. Ketersediaan unsur hara sangat berkaitan dengan aktivitas mikroba yang terlibat di dalamnya.

Berdasarkan laju pertumbuhan yang diamati pada bibit $R$. apiculata yang diberi perlakuan fungi A.niger mampu meningkatkan pertambahan diameter batang bibit $R$. apiculata sebesar $0,15 \mathrm{~cm} / 12$ minggu. Pertambahan diameter merupakan pertambahan dari hasil pembelahan pada proses pertumbuhan vegetatif pada tumbuhan. Bibit $R$. apiculata yang diberikan perlakuan pertambahan diameternya lebih tinggi dibandingkan dengan kontrol yaitu 0,09 cm/ 12 minggu. Aspergillus sp. memiliki kemampuan untuk mengubah $\mathrm{P}$ pada tanah yang tidak tersedia menjadi tersedia. Hal ini sesuai dengan pernyataan [10] bahwa pertumbuhan $R$. apiculata juga dapat ditingkatkan dengan memanfaatkan fungi, salah satunya ialah Aspergillus sp. yang mampu melarutkan ion $\mathrm{P}$ yang pada tanah serta mengurangi racun $\mathrm{Al}$. Ion P merupakan unsur yang dibutuhkan oleh tanaman untuk meningkatkan pertumbuhan batang dan akar tanaman. Fungi yang digunakan dapat diperoleh dengan melakukan dekomposisi serasah pada daerah sekitar tempat tumbuh tanaman R. apiculata.

\subsection{Lebar Daun}

Di daerah Pulau Sembilan lebar permukaan daun tertinggi terdapat pada bibit $R$. apiculata dengan perlakuan A. niger yaitu sebesar $4,05 \mathrm{~cm}$ sedangkan lebar daun terendah terdapat pada bibit $R$. apiculata yang tidak diberikan perlakuan (kontrol) yaitu 2,35 cm. Perbedaan luas daun tersaji pada Gambar 5.

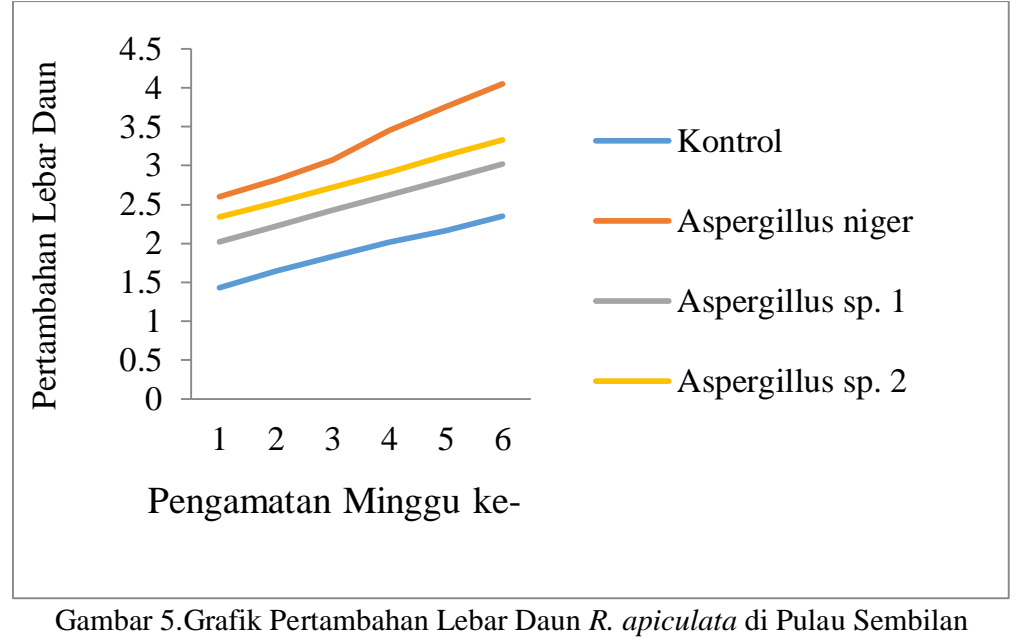

Berdasarkan hasil pengamatan yang telah dilakukan, lebar daun yang paling tinggi terdapat pada tanaman dengan perlakuan fungi Aspergillus niger dengan lebar daun 4,05 cm. Sedangkan untuk lebar daun terendah terdapat pada tanaman yang tidak diberikan perlakuan (kontrol) dengan lebar daun $2,35 \mathrm{~cm}$. Pada pengujian analisis sidik ragam 5 $\%$ diketahui bahwa pemberian fungi untuk meningkatkan lebar daun bibit $R$. apiculata berpengaruh nyata antar perlakuan. Laju pertumbuhan pada bibit $R$. apiculata tertinggi terjadi pada bibit yang diberikan perlakuan fungi jenis A. niger dengan nilai $1,45 \mathrm{~cm} / 12$ minggu. Perkembangan daun pada tumbuhan dipengaruhi oleh jenis unsur hara $\mathrm{N}$. Dengan pemberian perlakuan fungi yang diberikan mampu meningkatkan tersedianya unsur hara yang diserap oleh tanaman melalui proses perombakan yang dilakukan oleh aktivitas fungi. Sehingga dengan adanya aktivitas fungi mampu meningkatkan bentuk laju petumbuhan lebar daun pada bibit sebesar 1,45 cm selama 12 minggu dan laju pertumbuhan lebar daun terendah terdapat pada Aspergillus sp. 2 yaitu $0,99 \mathrm{~cm} / \mathrm{minggu}$.

\subsection{Jumlah Daun}

Pengamatan jumlah daun dilakukan dengan cara menghitung secara langsung jumlah daun pada bibit $R$. apiculata yang tumbuh di lapangan. Penghitungan daun ini dilakukan seterusnya selama masa pengamatan yaitu 12 minggu 
dengan total 6 kali pengamatan. Berdasarkan pengamatan di pulau Sembilan, Jumlah daun terbanyak terdapat pada bibit $R$. apiculata yang diberi perlakuan fungi $A$. niger yaitu sebanyak 10 helai daun sedangkan jumlah daun terendah terdapat pada bibit $R$. apiculata tanpa perlakuan (control) yaitu berjumlah 4 helai daun. Berdasarkan uji sidik ragam yang dilakukan, jumlah daun dipengaruhi oleh adanya pemberian fungi untuk meningkatkan kemampuan bibit $R$. apiculata untuk memperoleh tumbuhnya daun baru. Hasil Penghitungan yang dilakukan terhadap jumlah daun selama 12 minggu tersaji pada Gambar 6.

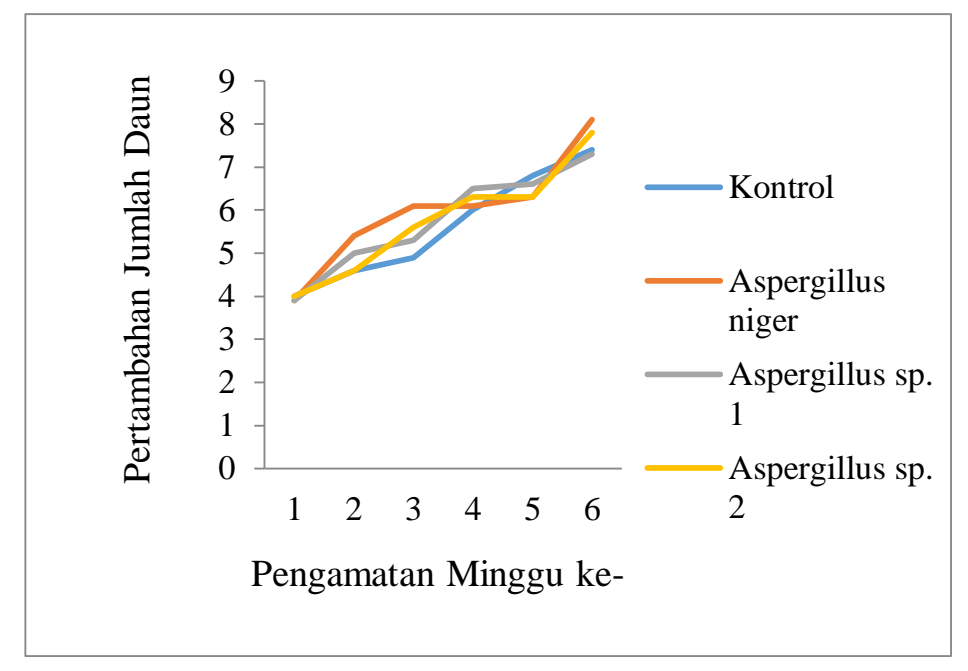

Gambar 6.Grafik Pertambahan Jumlah Daun R. apiculata di Pulau Sembilan

Daun merupakan bagian tanaman yang paling penting, hal ini dikarenakan daun merupakan alat yang digunakan tanaman untuk memperoleh makanan selain memanfaatkan akarnya dalam menyerap unsur hara dari dalam tanah tempat tumbuhnya. Pada pengamatan yang dilakukan di pulau Sembilan, jumlah daun terbanyak terdapat pada bibit $R$. apiculata dengan perlakuan fungi Aspergillus niger dengan jumlah 10 helai daun sedangkan untuk bibit $R$. apiculata dengan perlakuan lainnya memiliki jumlah daun yang sama yaitu 9 helai daun. Selanjutnya dilakukan uji Analisis sidik ragam dengan taraf 5\%, dan diperoleh bahwa pemberian fungi tidak memberikan pengaruh yang nyata untuk pertambahan jumlah daun $R$. apiculata. Semakin banyak daun maka akan semakin banyak proses fotosintesis dan akan semakin banyak makanan yang diproduksi.

Berdasarkan perhitungan laju pertumbuhan yang dilakukan, bibit $R$. apiculata yang berikan perlakuan fungi $A$. niger mampu meningkatkan jumlah daun sebanyak 4 helai/12 minggu. Unsur hara yang berperan dalam pertumbuhan daun ialah unsur hara N. Dengan memberikan perlakuan fungi mampu meningkatkan unsur hara $\mathrm{N}$ yang dibutuhkan oleh tumbuhan. Hal ini sesuai dengan pernyataan sebelumnya oleh [11] mengenai kemampuan Aspergillus sp. dalam merombak jenis unsur hara khususnya $\mathrm{N}$ sehingga tersedia didalam tanah.

\section{Kesimpulan dan Saran}

\subsection{Kesimpulan}

Fungi memiliki kemampuan berbeda-beda dalam meningkatkan laju pertumbuhan pada bibit Rhizophora apiculata. Dalam penelitian ini fungi Aspergillus niger memberikan manfaat paling baik yaitu mampu meningkatkan tersedianya unsur hara yang diserap oleh tanaman melalui proses perombakan yang dilakukan oleh aktivitas fungi bagi pertumbuhan mangrove. Pemberian perlakuan fungi Aspergillus niger terhadap bibit Rhizophora apiculata berpengaruh nyata pada tinggi batang, diameter batang dan lebar daun. 


\subsection{Saran}

Sebaiknya untuk mempercepat proses pertumbuhan bibit Rhizophora apiculata dapat mengunakan fungi Aspergillus niger yang berpengaruh nyata terhadap pertumbuhan tinggi, diameter, lebar daun.

\section{Referensi}

[1] Dharmawan M.L., Yunasfi, dan M. Basyuni (2015) "Pemanfaatan Fungi Aspergillus flavus, Aspergillus terreus, Dan Trichoderma harzianum Untuk Meningkatkan Pertumbuhan Bibit Bruguiera gymnorrhiza", Fakultas Kehutanan, Universitas Sumatera Utara

[2] Bismark M., Subiandono, E., dan Heriyanto, N. M. (2008) "Keragaman dan potensi jenis serta kandungan karbon hutan mangrove di sungai Subelen Siberut, Sumatera Barat." Jurnal Penelitian Hutan dan Konservasi Alam 5 (3): 297-306.

[3] Mulyadi E, O. Hendriyanto, dan Nurfitriani (2010) “Konservasi hutan Mangrovesebagai Ekowisata.” Teknik Lingkungan 1 (1): $51-57$.

[4] Irwanto (2008) "Hutan Mangrove dan Manfaatnya. Bagian Ekologi Dan Manajemen Satwaliar Departemen Konservasi Sumberdaya Hutan Dan Ekowisata", Fakultas Kehutanan IPB, Bogor

[5] Nababan R, Yunasfi, dan M. Basyuni (2015) "Pemanfaatan Berbagai Jenis Fungi Untuk Meningkatkan Pertumbuhan R. apiculata Di Desa Nelayan Indah Kecamatan Medan Labuhan (Utilization The Various Of Fungi To Increase The Growth Of R. Apiculata Seedlings In Desa Nelayan Indah Kecamatan Medan Labuhan)", Program Studi Kehutanan, Fakultas Pertanian, Universitas Sumatera Utara, Medan.

[6] Eliza D. (2014) "Fungi Aspergillus niger" Yogyakarta

[7] Das A.C. (1963) "Utilization of insoluble phosphate by soil fungi.” J. Indian Soc. Soil. Sci 11: 203-207.

[8] Elfiati D. (2005) "Peran Mikroba Pelarut Posfat terhadap Pertumbuhan Tanaman”, Jurusan Kehutanan, Fakultas Pertanian, Universitas Sumatera Utara, Medan

[9] Goenadi D.H.., R. Saraswati, N.N. Naganro, dan J.A.S. Adiningsih (1995) "Nutrient solu-bilizing and aggregate-stabilizing microbes isolated from selected humic tropical soil." Menara perkebunan 63 (2): 60-66.

[10] Sihombing I.K., Yunasfi, dan B. Utomo (2015) Pengaruh Fungi Aspergillus flavus, Aspergillus terreus, dan Trichoderma harzianum terhadap pertumbuhan bibit Avicennia officinalis." Peronema Forestry Science Journal 4 (4): 178-185.

[11] Ilyas M. (2007) "Isolasi dan Identifikasi Mikoflora Kapang pada Sampel Serasah Daun Tumbuhan di Kawasan Gunung Lawu, Surakarta, Jawa Tengah.” Biodiversitas 8 (2): 105-110. 